\title{
Tarburina zagrosiana n. gen., n. sp., a new larger benthic porcelaneous foraminifer from the late Maastrichtian of Iran
}

\author{
Felix Schlagintweit ${ }^{1}$, Koorosh Rashidi ${ }^{2}$ \& Farzaneh Barani $^{2}$ \\ ${ }^{1}$ Lerchenauerstr. 167, D-80935 München, Germany \\ 2 Department of Geology, Payame Noor University, PO Box 19395-3697 Tehran, Iran \\ *Correspondence: felix.schlagintweit@gmx.de
}

\begin{abstract}
A new larger benthic porcelaneous foraminifer of soritid affinity is described as Tarburina zagrosiana $\mathrm{n}$. gen., n. sp. from the late Maastrichtian of the Tarbur Formation, Zagros Zone, SW Iran. It occurs in foraminiferal-dasycladalean wackestones and packstones, in association with Loftusia ssp., dicyclinids/cuneolinids, Neobalkhania bignoti Cherchi \& Schroeder, Gyroconulina columellifera Schroeder \& Darmoian, Spirolina? farsiana Schlagintweit \& Rashidi, Broeckina cf. dufrenoyi (d'Archiac), other benthic foraminifers, and dasycladalean algae. Due to its elongate test and marginal chamber subdivision by aligned vertical partitions, Tarburina n. gen. can be compared with representatives of the Praerhapydionininae. The interio-marginal slit-like foramina/aperture of Tarburina represents an outstanding feature in complex porcelaneous taxa. The monospecific genus Tarburina is considered a Maastrichtian newcomer within the Late Cretaceous Global Community Maturation cycle of larger benthic foraminifera. A biostratigraphic and palaeobiogeographical restriction seems possible, as reported for many other Late Cretaceous larger benthic foraminifera.
\end{abstract}

Keywords: shallow-water carbonates, larger benthic foraminifera, Praerhapydioninidae, taxonomy, biostratigraphy, Zagros Zone

Received 16 May 2016; revised 8 June 2016; accepted 9 June 2016

The Late Cretaceous Tarbur Formation, named after the village of Tarbur (Fars Province), and cropping out in the SW Zagros basin, represents a predominantly carbonate lithostratigraphic unit that contains rich microfauna and microflora associated with rudists (James \& Wynd 1965). It extends from the NW to the SE of the Zagros basin along the western edge of the imbricated Zagros Zone, between the main Zagros fault and the Sabzposhan fault to the east (Alavi 2004). Towards the SW, the Tarbur Formation interfingers with the Gurpi Formation that usually underlies the former. In the Stratigraphic Chart of Iran provided in 1995 by the Geological Society of Iran, the Tarbur Formation is assigned to the CampanianMaastrichtian interval (Fig. 1), following the pioneering work of James \& Wynd (1965). The rudist fauna of the Tarbur Formation has already been described by several authors (e.g. Douvillé 1904; Kühn 1932; Khazaei et al. 2010). In contrast, the micropalaeontological content of the Tarbur Formation is still poorly constrained and taxonomic studies are lacking. Some taxa of calcareous algae and benthic foraminifera, often improperly illustrated, are indicated and illustrated in various recently published papers (Vaziri-Moghadam et al. 2005; Afghah 2009, 2016; Maghfouri-Moghaddam et al. 2009; Rajabi et al. 2011; Abyat et al. 2012, 2015; Afghah \& Farhoudi 2012; Pirbaluti \& Abyat 2013; Pirbaluti et al. 2013; Afghah \& Yaghmour 2014). Several determinations, however, are incorrect and therefore need revision (e.g. Schlagintweit et al. 2016a, b).

In the present paper, the new porcelaneous larger benthic foraminifer Tarburina zagrosiana n. gen., n. sp. is described from the upper part of the Tarbur Formation.

\section{Studied section}

The study area, located in the High Zagros Belt, is situated north of Mount Dena, about $65 \mathrm{~km}$ south of the town of Semirom. The section of the Tarbur Formation is exposed about $10 \mathrm{~km}$ south of the village of Mandegan, and is here named the Mandegan section (Fig. 2). Here the Tarbur Formation with a thickness of c. $272 \mathrm{~m}$ overlies conformably the Gurpi Formation. The top of the section is unconformably overlain by conglomerates of the Pliocene Bakhtiari Formation (see Bahrami 2009, for details). Based on the lithostratigraphy, the section has been divided into three units (from base to top; Fig. 3): unit 1 is dominated by thick-bedded limestones; unit 2 mostly contains medium-bedded limestones with intercalated marly limestone layers; and unit 3 consists of marly limestones. The Greenwich coordinates of the section base are $\mathrm{N}$ $31^{\circ}, 25^{\prime}, 8.13^{\prime \prime}$ and $\mathrm{E} 51^{\circ}, 24^{\prime}, 34.58^{\prime \prime}$.

Based on larger benthic foraminifera (e.g. Loftusia ssp., Siderolites calcitrapoides Lamarck, Gyroconulina columellifera Schroeder \& Darmoian, Omphalocyclus macroporus (Lamarck)), the Tarbur Formation of the Mandegan section is Maastrichtian in age (see discussion in Schlagintweit et al. 2016a, b). Neobalkhania bignoti was originally described by Cherchi et al. (1991) from the late Maastrichtian of Croatia. They also noted its occurrence in timeequivalent strata from Greece, leading Cherchi et al. (1991, p. 288) to conclude that $N$. bignoti represents 'an excellent marker of this time interval' (see also Fleury 2014, fig. 3). In the Mandegan section, the first dasycladalean algae, including Pseudocymopolia anadyomenea (Elliott) and Salpingoporella pasmanica Radoičić, for example, appear almost together for the first time in the section (from base to top) with some larger benthic foraminifera such as Loftusia spp., G. columellifera and N. bignoti in the upper part of unit 1 (Fig. 3). First specimens of Tarburina zagrosiana n. gen., n. sp. are observed in the upper part of unit 1 , persisting through units 2 to 3. In conclusion, a late Maastrichtian age for the samples with $T$. zagrosiana is most likely.

\section{Material and methods}

The specimens illustrated in this paper comprise 15 thin-sections. One part, including six thin-sections, is deposited at the Bayerische Staatssammlung für Paläontologie und historische Geology, Munich, under the official numbers SNSB-BSPG 2016V 4 


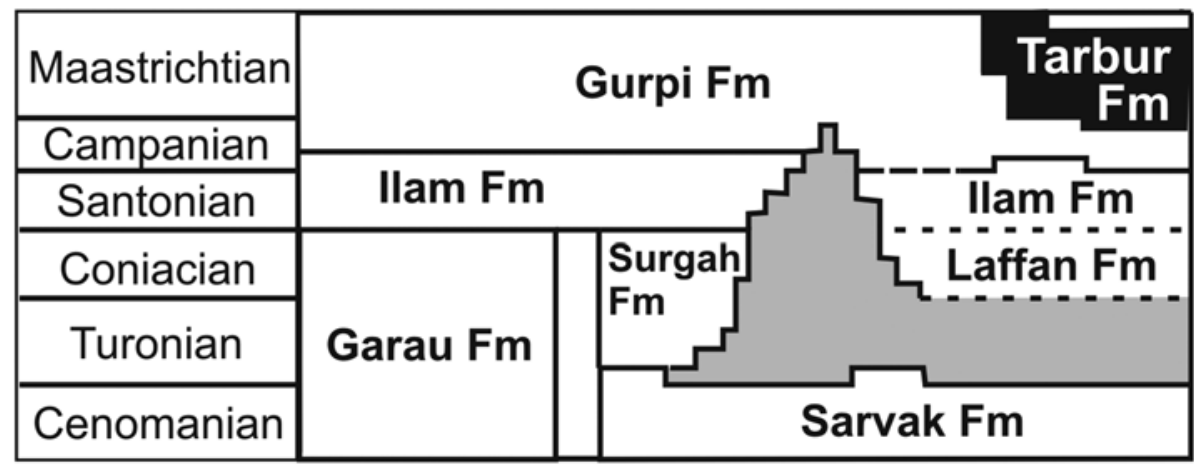

Fig. 1. Lithostratigraphy of the Upper Cretaceous strata of the Zagros Zone (redrawn from the Stratigraphic Chart of Iran, Geological Society of Iran, 1995). Tarbur Formation indicated in black; grey shaded area is stratigraphical gap. (sample Rt 72, including the holotype), V 5 (Rt 72-1), V 6 (sample Rt 79), V 7 (Rt 87), V 8 (sample Rt 89), 12 (sample Rt 102-2). The other part, including nine thin-sections, is deposited at the Ardakan
Payame Noor University, Iran, collection Rashidi, under the original sample numbers Rt 61, Rt 62-1, Rt 64, Rt 67-3, Rt 70, Rt 72-2, Rt 82 , Rt 85 , and Rt 87.

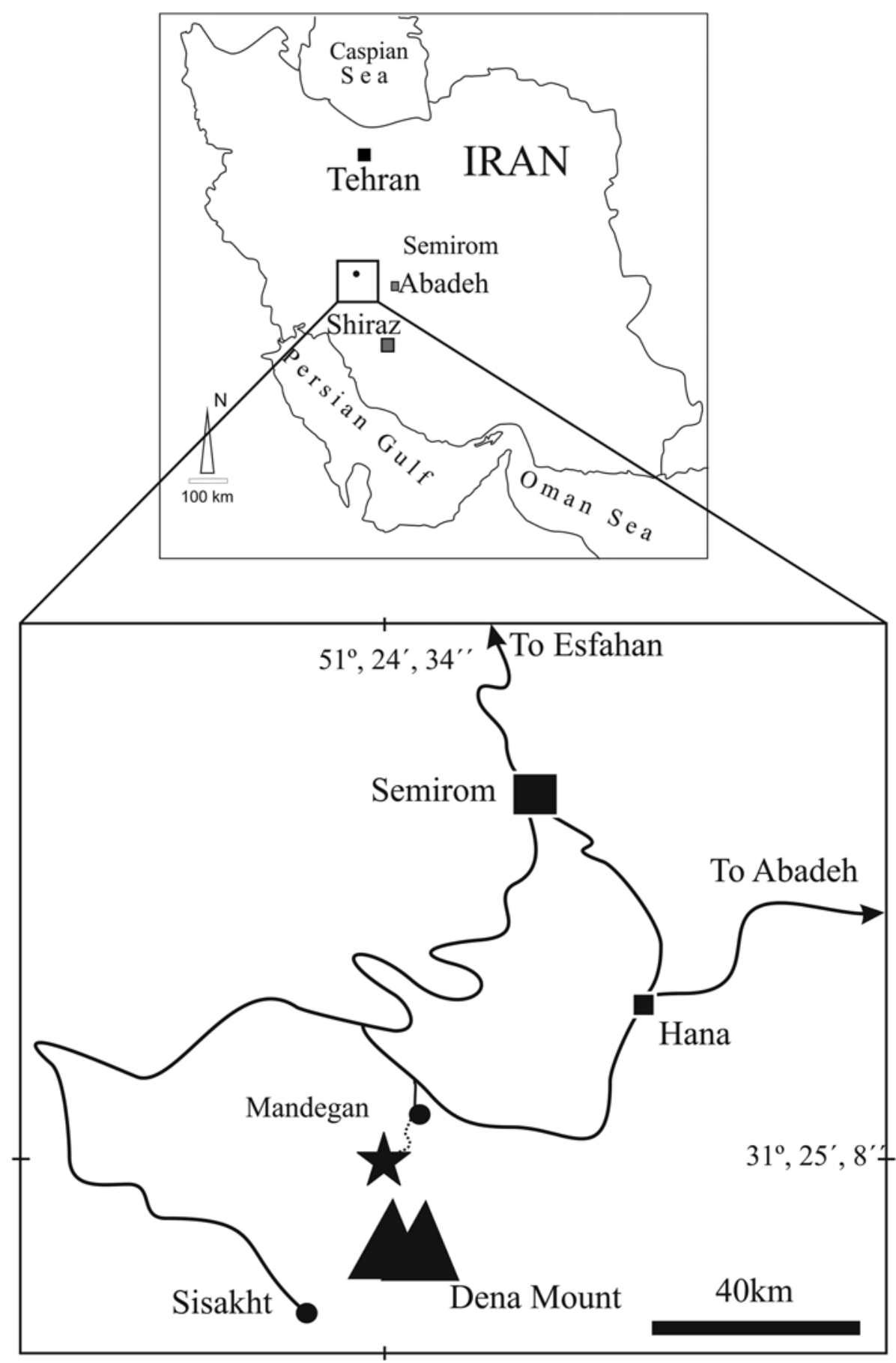

Fig. 2. Location of the type-locality of Tarburina zagrosiana n. gen., n. sp. 


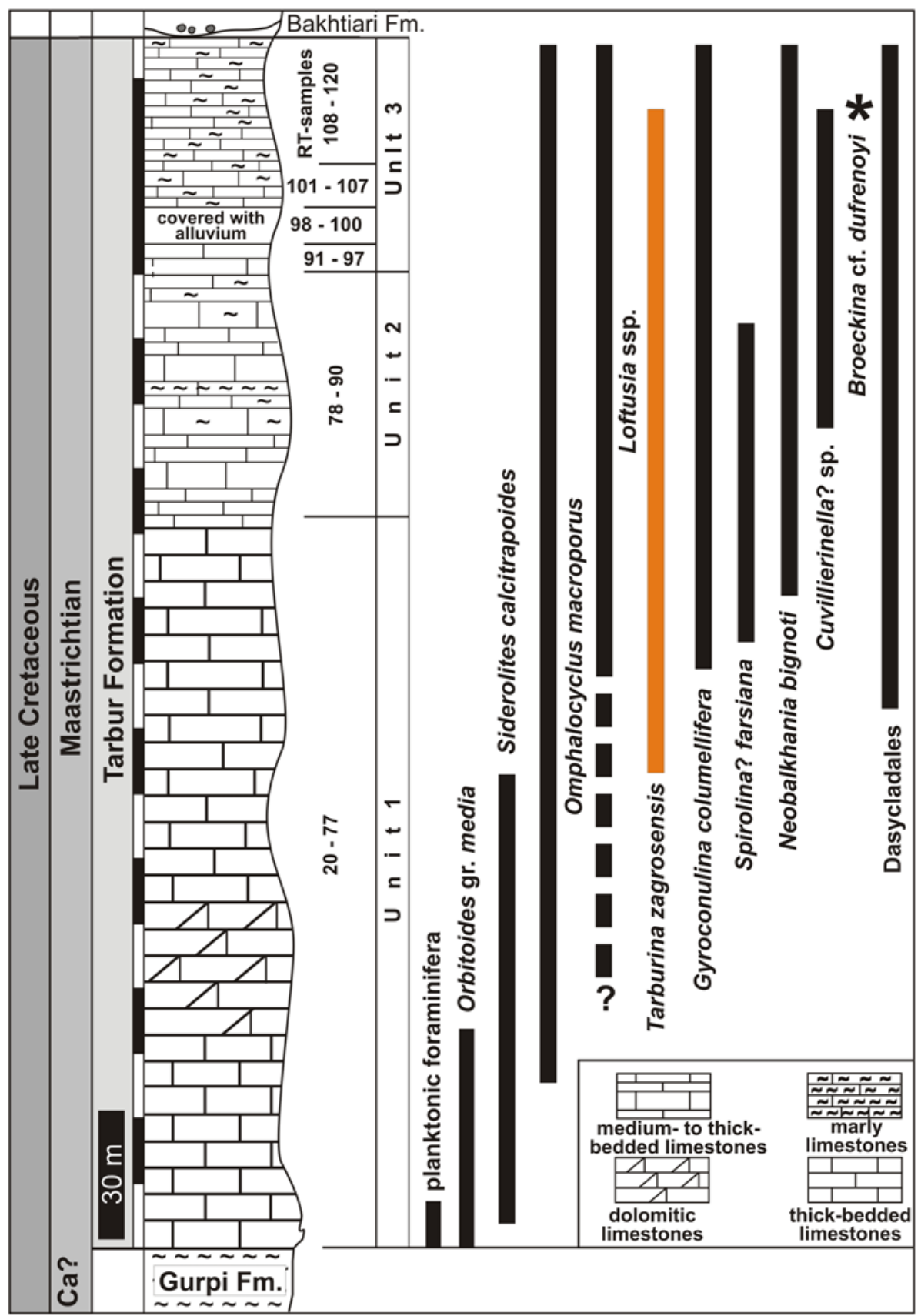

Fig. 3. Distribution of selected taxa of larger benthic foraminifera and dasycladalean algae in the Tarbur Formation of the Mandegan section.
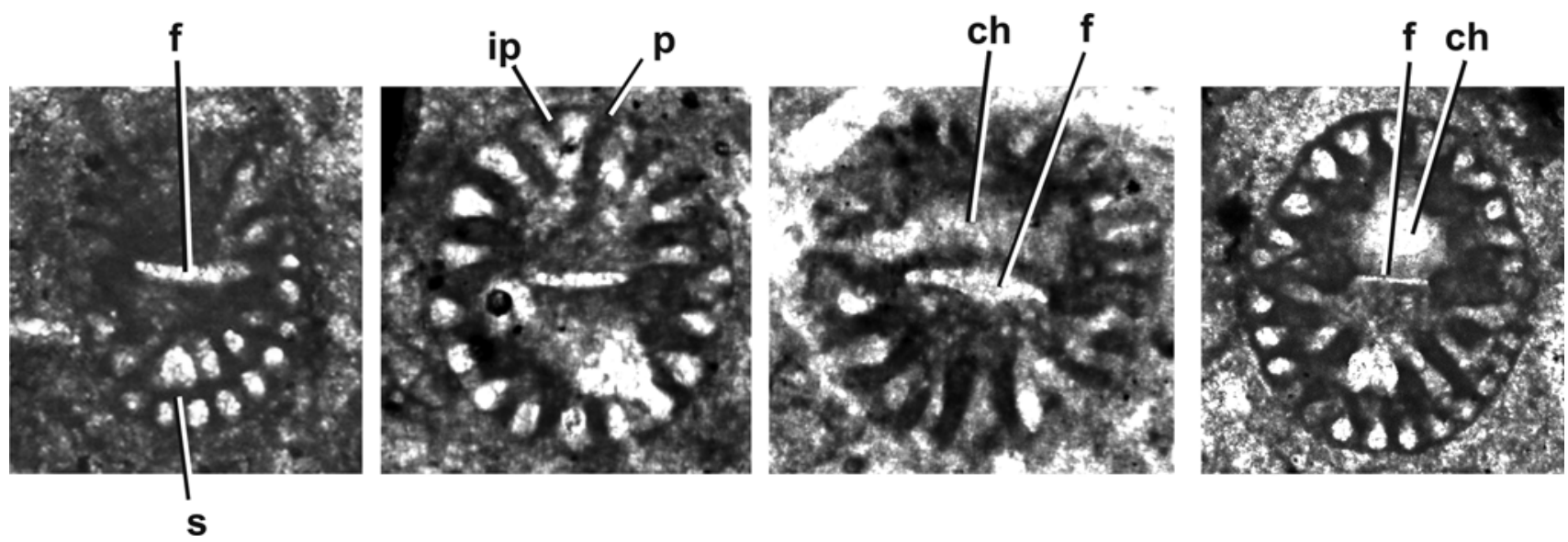

Fig. 4. Some transverse and oblique-transverse sections of Tarburina zagrosiana n. gen., n. sp. showing slit-like basal foramina and other structural features. ch, chamber; f, foramen; ip, intercalary partition; p, (vertical) partition; s, septum. Without scale. 


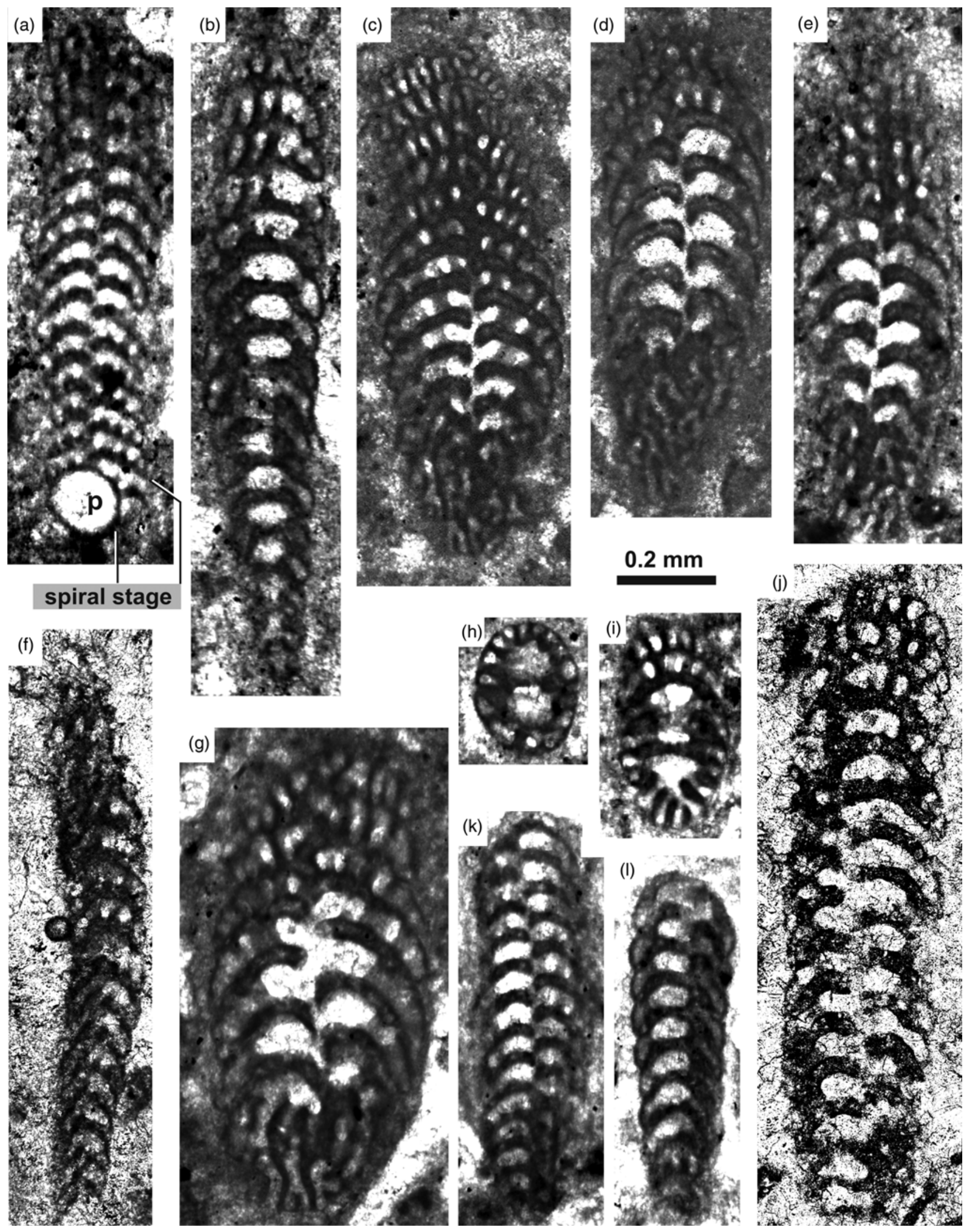

Fig. 5. (a-j) Tarburina zagrosiana n. gen., n. sp.: (a) longitudinal section in plane of biseriality, showing short coiled stage with megalospheric embryo, holotype; (b) longitudinal section, tangential in the upper part; (c-e) longitudinal-tangential section in the plane of biseriality showing aligned septula. (f, j, k-l) longitudinal-oblique sections. (h) slightly oblique transverse section. (g, i) oblique sections. p, protoconch. Thin-sections: SNSB-BSPG 2016V 5 (a and e), V 6 (b), Rt 87 (c), Rt 67-3 (d), Rt 64 (f, j), BSPG IX-2016V 7 (g), V 4 (h, i), V 8 (k), V 12 (l).

\section{Systematic palaeontology}

The high-rank classification follows Pawlowski et al. (2013). For the low-rank classification see Consorti et al. (2016) and remarks below. For the glossary, refer to Hottinger (2006).
Phylum Foraminiferida d'Orbigny, 1826

Class Tubothalamea Pawlowski et al., 2013

Order Miliolida Delage \& Hérouard, 1896, emend. Pawlowski et al., 2013 

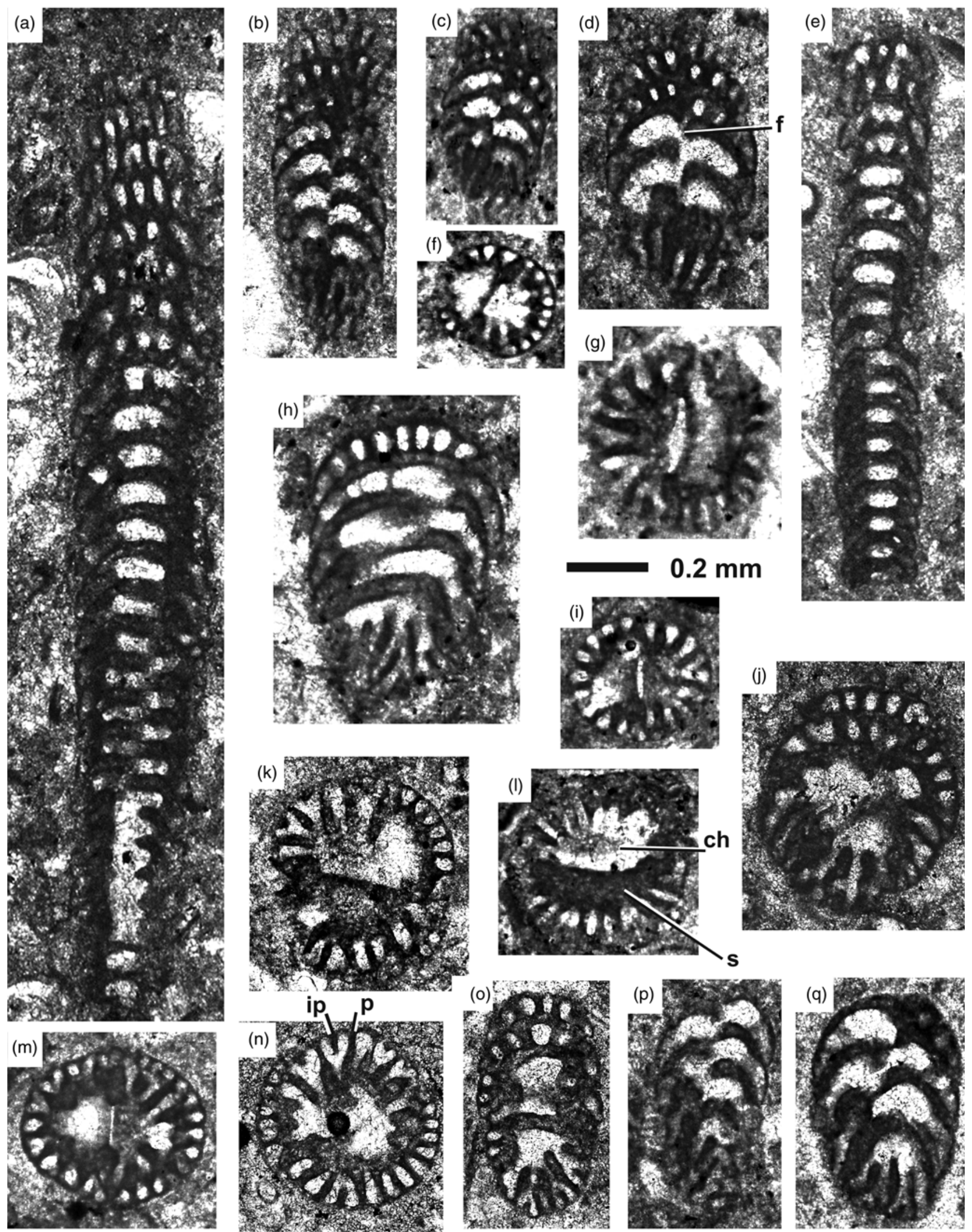

Fig. 6. (a-q) Tarburina zagrosiana n. gen., n. sp.: (a, e) longitudinal sections (upper part tangential) in the plane perpendicular to biseriality; (a) showing alignment of partitions. ( $\mathbf{b}-\mathbf{d}, \mathbf{h}, \mathbf{j}, \mathbf{o}-\mathbf{q})$ oblique sections; (f, $\mathbf{g}, \mathbf{i}, \mathbf{k}-\mathbf{n})$ transverse sections. ch, chamber; $f$, foramen; ip, intercalary partition; $p$, (vertical) partition; s, septum. Thin-sections: Rt 82 (a, j, n), Rt 70 (b, d, p-q), Rt 87 (e, g), SNSB-BSPG 2016V 4 (f, i, l), Rt 72-2 (h), Rt $62-1$ (k), Rt 85 (m), Rt 61 (o).

?Superfamily Soritoidea Ehrenberg, 1839

Remarks. According to Consorti et al. (2016, p. 149), representatives of the superfamily Soritoidea should be restricted to those porcelaneous foraminifera 'with planispiral early arrangement of chambers in A and B generations that may later become uniserial, flabelliform, or annular'. Due to its biserial test, the new genus Tarburina, is only tentatively placed in the Soritoidea and the 

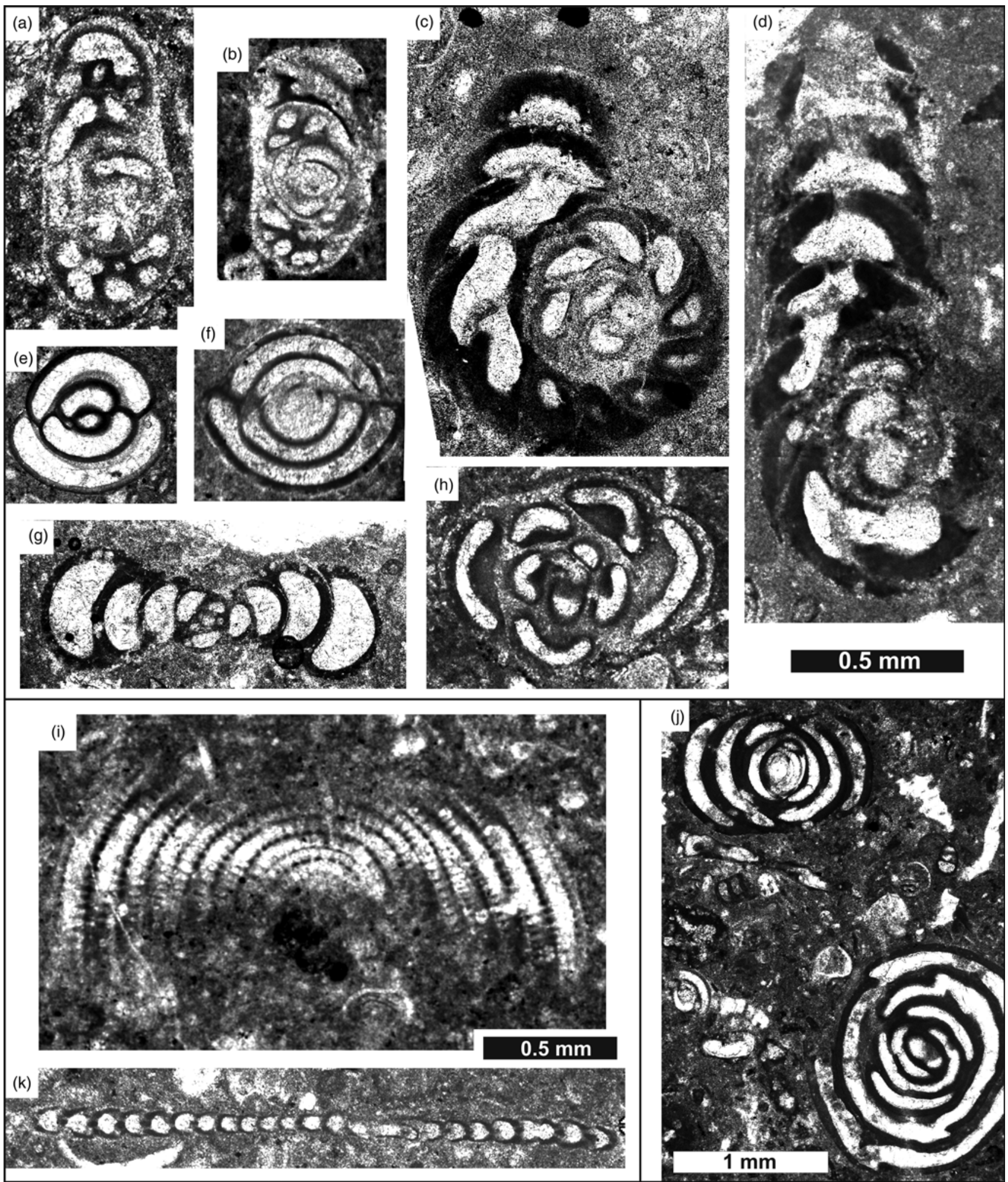

Fig. 7. (a, b) Cuvillerinella? sp., slightly oblique axial sections. (c, d) Spirolina? farsiana Schlagintweit \& Rashidi, equatorial section (c), oblique equatorial section (d). (e, f) Pyrgo? sp., subaxial sections. (g) Dargenioella? sp., axial section. (h) Quinqueloculina sp., transverse section. (i, k) Broeckina aff. dufrenovi (d' Archiac), slightly oblique equatorial section (i), subaxial section (k). (j) Pseudonummoloculina kalantarii Schlagintweit \& Rashidi Thinsections: Rt 113-3 (a), SNSB-BSPG 2016V 16 (b, f, i), Rt 67-2 (c), Rt 67-3 (d), SNSB-BSPG 2016V 17 (e), Rt 86 (g), Rt 83 (h), NG 85 (j), Rt 113-2 (k)

lower-rank categories. Further studies are needed to assess its suprageneric position before a final conclusion is made (e.g. emendation of the Soritoidea).

?Family Praerhapydioninidae Hamaoui \& Fourcade, 1973

?Subfamily Praerhapydionininae sensu Consorti, Boix \& Caus, 2016
Remarks. The subfamily Praerhapydioninidae was established by Hamaoui \& Fourcade (1973), including forms with both multiple and single apertures. It was raised to family level by Consorti et al. (2016, p. 149) and should include 'all the Soritoideans with planispiral-involute chamber arrangement in the early stage of growth that may become uncoiled or flabelliform-to-cyclical in the adult stage, independently of the shape, number and position of the 
apertures'. In addition, Consorti et al. (2016) created the new subfamily Praerhapydioniniae 'restricted to the genera with a single aperture' (Consorti et al. 2016, p. 150). The Praerhapydioninae include Late Cretaceous and Palaeogene taxa.

Genus Tarburina n. gen.

Type species. Tarburina zagrosiana n. sp.

Derivation of name. The genus name refers to the late Cretaceous (Campanian?, Maastrichtian) Tarbur Formation of the Zagros Zone in southwestern Iran.

Diagnosis. Test cylindro-conical, of circular to oval transverse section, and convex apertural face. It is formed by a large globular proloculus followed by few, ?planispirally coiled chambers; adult part with up to 28 pairs of biserial low and broad chambers that strongly curve back over the top of the previous chambers. Sutures depressed. Chambers partly subdivided by vertical (radial) partitions, often continuous from one chamber to the next, and forming elongate rectangular cortical chamber subdivisions. Between the main vertical partitions, shorter secondary partitions may be intercalated. There are no pillars. Foramina basal, represented by a simple, elongated slit. Wall calcareous porcelaneous.

Remarks. On account of its gross morphology (short spiral stage followed by a prominent enrolled straight part) and exoskeletal features, Tarburina n. gen. shares some similarities with Rhapydionina Stache, 1913 (type-species Peneroplis liburnica Stache, 1889, Maastrichtian of Slovenia). The new genus mainly differs from the latter in its adult uncoiled part composed of biserially arranged chambers instead of rectilinear chambers connected by multiple cribrate foramina in Rhapydionina. The biserial chamber arrangement along with its apertural type generally represents an outstanding characteristic among the group of Late Cretaceous complex porcelaneous benthic foraminifera of the superfamily Soritoidea (e.g. Henson 1950; Hottinger 2007; Boudagher-Fadel 2008).

\section{Tarburina zagrosiana $\mathrm{n}$. sp.} (Figs 4-6)

Derivation of name. The species name refers to the Zagros Zone of SW Iran.

Diagnosis. See diagnosis of the monotypic genus.

Holotype. Subaxial section, illustrated in Figure 5a, thin-section SNSB-BSPG 2016V 4 deposited at the Bayerische Staatssammlung für Paläontologie und Geologie, Munich.

Material. About 90 random sectioned specimens in 15 thinsections.

Horizon and locality. Late Maastrichtian marly limestones of the Tarbur Formation of the Mandegan section (Fig. 2).

Description. Test free, an elongated cone (subcylindrical to acute conical); may be up to six times longer than wide (Fig. 6a). Transverse sections mostly circular, but may also be slightly compressed in the plane of biseriality, thus attaining oval sections (Fig. 5h and f). Dimorphism most likely, expressed by slender megalospheric (Fig. 5a) and broader microspheric forms (Fig. 5g). Megalospheric forms start with a spherical proloculus followed by one whorl with only a few ?planispirally coiled chambers (Fig. 5a). The reduced early stage is followed by a prominent uncoiled adult stage composed of biserially arranged chambers (up to 31 pairs,
Fig. 6a). The chambers and septa strongly curve back over the top of the previous chambers. In longitudinal sections perpendicular to the plane of biseriality, the chambers appear sickle-shaped (e.g. Fig. 6a and d). Per $0.5 \mathrm{~mm}$ of axial length there are $14-16$ chambers ( $=7$ to 8 pairs) in the uncoiled test part. The thickness of the septa is slightly less than the chamber height. Chambers subdivided by vertical (radial) partitions (septula), often continuous from one chamber to the next, and forming elongate rectangular cortical chamber subdivisions (Figs $5 \mathrm{c}$ and $6 \mathrm{a}$ ). Shorter secondary partitions may be present (Fig. 6k and n). The thickness of the partitions is less than the one of the septa. Number of partitions and secondary partitions is directly related to the test diameter $(D)$, ranging from 20 $(D=0.27 \mathrm{~mm})$ up to $38(D=0.46 \mathrm{~mm})$. Foramina basal, represented by a simple, elongated slit (Fig. 4). In longitudinal sections perpendicular to the plane of biseriality, the foramina between successive chambers may display a zig-zag pattern or an almost aligned arrangement (Figs 5a, c, e and 6d). Wall calcareous porcelaneous.

Dimensions. Length: up to $2.8 \mathrm{~mm}$. Test thickness: up to $0.5 \mathrm{~mm}$ (supposed B-forms, e.g. Fig. 5g). Proloculus inner diameter: $0.13 \mathrm{~mm}$ ( 1 value).

Thickness of vertical partition: $c .0 .01-c .0 .02 \mathrm{~mm}$. Number of chambers in the uncoiled part: up to 62 (31 pairs).

Microfacies and associations. Tarburina zagrosiana is observed in foraminiferan-dasycladalean wackestones to packstones, soft substrate deposits of a shallow protected lagoon with very low water energy. This can be inferred from the association of agglutinated conical foraminifera (Orbitolinidae, Gyroconulina, Dictyoconella), miliolaceans [among larger taxa as Broeckina aff. dufrenoyi (d' Archiac), Spirolina? farsiana Schlagintweit \& Rashidi, Cuvillierinella? sp., Pseudonummoloculina kalantarii Schlagintweit \& Rashidi, Fig. 7], and dasycladalean algae. Except for the lack of alveolinids, and the presence of rudists, the association of porcelaneous taxa observed in the uppermost part of the Tarbur Formation of the Mandegan section can be compared palaeoecologically with equivalent associations of the Palaeogene (e.g. Vecchio \& Hottinger 2007), e.g. the so-called 'Spirolina facies' (e.g. Sartoni \& Crescenti 1962; Radoičić 1995) or 'Facies à Imperforés' (e.g. Fleury 1997) of the Mediterranean area. It is typically referred to a restricted lagoonal setting (Barattolo et al. 2000).

\section{Concluding remarks}

Both the Rhapydioninidae and Praerhapydioninidae (including the subfamily Pseudorhapidionininae) represent biostratigraphically important groups of porcelaneous larger benthic foraminifera widely distributed often in restricted lagoonal settings of Late Cretaceous carbonate platforms (e.g. Stache 1913; De Castro 1972; Vicedo et al. 2011; Fleury 2014; Consorti et al. 2015, 2016). They exhibited a marked diversification during the CampanianMaastrichtian and were also used for biozonations (e.g. Fleury 1980, 2014). The Late Cretaceous representatives are separated from their Late Palaeogene descendants of unknown phylogenetic relationship by a considerable stratigraphic gap (Boudagher-Fadel 2008). The Palaeogene representatives, however, are all structurally different from the Late Cretaceous forms and were given discrete other names (Hottinger 2007).

The monospecific genus Tarburina is considered a Maastrichtian newcomer of soritoidean affinity within the Late Cretaceous Global Community Maturation cycle of larger benthic foraminifera (Hottinger 2001). It occurs in typically inner platform depositional settings and, in some parts of the Tarbur Formation, may be a typical constituent of an association of larger porcelaneous taxa that in the Palaeogene is known as Spirolina facies and that is referred to a 
restricted lagoonal setting (e.g. Sartoni \& Crescenti 1962; Radoičić 1995; Fleury 1997; Barattolo et al. 2000; Vecchio \& Hottinger 2007). Tarburina zagrosiana is thus far only recorded from the late Maastrichtian of the Tarbur Formation of the Zagros Zone as part of the southern Tethyan margin, here the Arabian plate. Thus, a biostratigraphic and palaeobiogeographical restriction seems possible, as reported from many other late Cretaceous larger benthic foraminifera (e.g. Fleury et al. 1985; Goldbeck \& Langer 2009).

\section{Acknowledgements and Funding}

Helpful discussion with Sylvain Rigaud (Singapore) is kindly acknowledged. Our thanks also go to the reviewers Antonietta Cherchi (Cagliari) and Lorenzo Consorti (Barcelona) for providing constructive and helpful remarks.

Scientific editing by Sev Kender

\section{References}

Abyat, A., Afghah, M. \& Feghhi, A. 2012. Stratigraphy and foraminiferal biozonation of Upper Cretaceous sediments in southwest Sepid Dasht, Lurestan, Iran. Australian Journal of Basic and Applied Sciences, 6, 18-26.

Abyat, A., Afghah, M. \& Feghhi, A. 2015. Biostratigraphy and lithostratigraphy of Tarbur Formation (Upper Cretaceous) in southwest of Khorram Abad (southwest Iran). Carbonates and Evaporites, 30, 109-118.

Afghah, M. 2009. New investigations of the Tarbur Formation lithostratigraphy in the review of type section and its correlation with Kuh-e Tir section. Journal of Sciences Islamic Azad University, 19, 183-196.

Afghah, M. 2016. Biostratigraphy, facies analysis of Upper Cretaceous-Lower Paleocene strata in South Zagros Basin (southwestern Iran). Journal of African Earth Sciences, 119, 171-184.

Afghah, M. \& Farhoudi, G. 2012. Boundary between Upper Cretaceous and Lower Paleocene in the Zagros Mountain Ranges of southwestern Iran. Acta Geologica Sinica, 86, 325-338.

Afghah, M. \& Yaghmour, S. 2014. Biostratigraphy study of Tarbur Formation (Upper Cretaceous) in Tang-E Kushk and east of Sarvestan (SW of Iran). Journal of Earth Science, 25, 263-274.

Alavi, M. 2004. Regional stratigraphy of the Zagros foldthrust belt of Iran and its proforeland evolution. American Journal of Science, 30, 1-20.

Bahrami, M. 2009. Sedimentology and paleogeography of the Bakhtyari conglomeratic formation at Ghalat and Garu-Charmakan Mountains, NW of Shiraz, Iran. Journal of Geology, Geophysics and Geosystems, 3, 1-10.

Barattolo, F., Romano, R. \& Vecchio, E. 2000. The Spirolina facies (EarlyMiddle Eocene) in Southern Appenines. Annali del' Universita di Ferrara, 8, 5-35.

Boudagher-Fadel, M.K. 2008. Evolution and geological significance of larger benthic foraminifera. Developments in Palaeontology \& Stratigraphy, 21, $1-548$.

Cherchi, A., Radoičić, R. \& Schroeder, R. 1991. Neobalkhania bignoti n. gen., n. sp., grand Foraminifère du Maastrichtian supérieur du Sud-est de 1'Europe. Comptes Rendus de l'Academie des Sciences, Série II, 313, 287-292.

Consorti, L., Caus, E., Frijia, G. \& Yazdi-Moghadam, M. 2015. Praetaberina new genus (type-species Taberina bingistani Henson, 1948): a stratigraphic marker for the Late Cenomanian. Journal of Foraminiferal Research, 45, 378-389.

Consorti, L., Boix, C. \& Caus, E. 2016. Pseudorhapydionina bilottei n. sp., an endemic foraminifera from the post-Cenomanian/Turonian boundary (Pyrenees, NE Spain). Cretaceous Research, 59, 147-154.

De Castro, P. 1972. Osservazioni sui generi Rhapydionina Stache e Rhipidionina Stache (Foraminiferida). Atti Accademia Pontaniana, 21, 1-42.

Delage, Y. \& Hérouard, E. 1896. Traité de Zoologie Concrète, Vol. 1, La Cellule et les Protozoaires. Schleicher Frères, Paris.

d'Orbigny, A. 1826. Tableau méthodique de la classe des Céphalopodes. Annales des Sciences Naturelles, 7, 245-314.

Douvillé, H. 1904. Etudes Géologiques. Partie 4, Paléontologie, Mollusques fossiles. In: Morgan, J.D. (ed.) Mission Scientifique en Perse, 3, 191-380. Ernest Leroux, Paris.

Ehrenberg, C.G. 1839. Über die Bildung der Kreidefelsen und des Kreidemergels durch unsichtbare Organismen. Physikalische Abhandlungen der Königlichen Akademie der Wissenschaften zu Berlin, 1838(1840: separate 1839), 59-147.

Fleury, J.-J. 1980. Les zones de Gavrovo-Tripolitza et du Pinde-Olonos (Grèce continentale et Péleponnèse du Nord). Evolution d'une plate-forme et d'un bassin dans leur cadre alpin. Société géologique du Nord, 4, 1-651.

Fleury, J.-J. 1997. Eocene soritids with ribs and/or faint sub-epidermal partitions: The genera Spirolina, Praerhapydionina and Paraspirolina n. gen. in the middle to upper Eocene 'Facies à Imperforés' of Greece. Revue de Micropaléontologie, 40, 297-311.
Fleury, J.-J. 2014. Données nouvelles sur Rhapydionina Stache, 1913 et Fanrhapydionina n. gen., un groupe de Rhapydioninidae (Alveolinacea, Foraminifera) foisonnant en région périadriatique au CampanienMaastrichtien. Geodiversitas, 36, 173-208.

Fleury, J.-J., Bignot, G., Blondeau, A. \& Poignant, A. 1985. Biogéographie de foraminifères téthysiens du Sénonien à l'Eocène supérieur. Bulletin de la Societé Géologique de France, (8), I, 5, 757-770.

Goldbeck, E.J. \& Langer, M.R. 2009. Biogeographic provinces and patterns of diversity in selected Upper Cretaceous (Santonian-Maastrichtian) larger foraminifera. In: Demchuk, T.D. \& Gary, A.C. (eds) Problem Solving with Microfossils. SEPM Special Publications, 93, 187-232.

Hamaoui, M. \& Fourcade, E. 1973. Révision des Rhapydioniniae (Alveolinidae, foraminifères). Bulletin du Centre de Recherches de Pau, 7, 361-393.

Henson, F.R.S. 1950. Middle Eastern Tertiary Peneroplidae (Foraminifera), with remarks on the phylogeny and taxonomy of the Family. West Yorkshire Printing Co., Wakefield.

Hottinger, L. 2001. Learning from the past? In: Box, E. \& Pignatti, S. (eds) Volume IV: The Living World. Part Two. Academic Press, San Diego, 449-477.

Hottinger, L. 2006. Illustrated glossary of terms used in foraminiferal research Carnets de Géologie/Notebooks on Geology, Memoir 2006/02, 1-126.

Hottinger, L. 2007. Revision of the foraminiferal genus Globoreticulina Rahagi, 1978 , and of its associated fauna of larger foraminifera from the late Middle Eocene of Iran. Carnets de Géologie/Notebooks on Geology, Article 2007/06 (CG2007_A06).

James, G.A. \& Wynd, J.G. 1965. Stratigraphic nomenclature of Iranian Oil Consortium Agreement Area. American Association of Petroleum Geologists Bulletin, 49, 2218-2232.

Khazaei, A.R., Skelton, P.W. \& Yazdi, M. 2010. Maastrichtian rudist fauna from Tarbur Formation (Zagros Region, SW Iran): Preliminary observations. Turkish Journal of Earth Sciences, 19, 703-719.

Kühn, O. 1932. Rudistae from Eastern Persia. Records of the Geological Survey of India, 46, 151-179.

Maghfouri-Moghaddam, I., Zarei-Sahamieh, R., Ahmadi-Khalaji, A. \& Tahmasbi, Z. 2009. Microbiostratigraphy of the Tarbur Formation, Zagros Basin, Iran. Journal of Applied Sciences, 9, 1781-1785.

Pawlowski, J., Holzmann, M. \& Tyszka, J. 2013. New supraordinal classification of Foraminifera: Molecules meet morphology. Marine Micropaleontology, 100, 1-10.

Pirbaluti, B.A. \& Abyat, A. 2013. Microbiostratigraphy and lithostratigraphy of the Tarbur Formation in southeast of Shahr-e-kord, Iran. Advances in Environmental Biology, 7, 3481-3486.

Pirbaluti, B.A., Ataabadi, M.M., Djafarian, M.A., Khosrow Tehrani, K., Afghah, M. \& Davoudi Farad, Z. 2013. Biostratigraphy and regional aspects of the Tarbur Formation (Maastrichtian) in Central Zagros, Southwest Iran. Rivista Italiana di Paleontologia e Stratigrafia, 119, 215-227.

Radoičić, R. 1995. On the age of limestones with Actinoporella kukoci Radoičić, 1975 and Praturlonella salernitana Barattolo, 1978 (Dasycladacean algues). Revue de Paléobiologie, 14, 95-105.

Rajabi, P., Safizadeh, M. \& Nowroozpour, H. 2011. Microbiostratigraphy and microfacies of Tarbour Formation in Makhmal-kuh (north east of Khorram Abbad-Iran). Journal of Basic and Applied Scientific Research, 1, 1724-1731.

Sartoni, S. \& Crescenti, U. 1962. Ricerche biostratigrafiche nel Mesozoico dell'Appennino meridionale. Giornale di Geologia, 29, 161-388.

Schlagintweit, F., Rashidi, K. \& Kivani, F. 2016a. On the occurrence of Salpingoporella pasmanica Radoičić, 2002, (Dasycladales) from the Late Maastrichtian Zagros Zone of Iran. Acta Palaeontologica Romaniae, 12, 33-42.

Schlagintweit, F., Rashidi, K. \& Barani, F. (2016b). First record of Gyroconulina columellifera Schroeder \& Darmoian, 1977 (larger benthic foraminifera) from the Maastrichtian Tarbur Formation of SW Iran (Zagros Fold-ThrustBelt). GeoPersia 6, 169-185, https://doi.org/10.22059/jgeope.2016.58675.

Stache, G. 1889. Die Liburnische Stufe und deren Grenz-Horizonte, eine Studie über die Schichtenfolge der Cretacisch-Eocänen oder Protocänen Landbildungsperiode im Bereiche der Küstenländer von Österreich-Ungarn. Abhandlungen der Geologischen Reichsanstalt, 13, 1-170.

Stache, G. 1913. Über Rhipidionina St. und Rhapydionina St. Jahrbuch der Geologischen Reichsanstalt, 62, 659-680.

Vaziri-Moghadam, H., Safari, A. \& Taheri, A. 2005. Microfacies, palaeoenvironment and sequence stratigraphy of the Tarbur Formation in the Kherameh area, SW Iran. Carbonates and Evaporites, 20, 131-137.

Vecchio, E. \& Hottinger, L. 2007. Agglutinated conical foraminifera from the Lower-Middle Eocene of the Trentinara Formation (southern Italy). Facies, 53, 509-533.

Vicedo, V., Frijia, G., Parente, M. \& Caus, E. 2011. The Late Cretaceous genera Cuvillierinella, Cyclopseudedomia, and Rhapydionina (Rhapydioninidae, Foraminiferida) in shallow-water carbonates of Pylos (Peloponese, Greece). Journal of Foraminiferal Research, 41, 167-181. 